\title{
Prawne uwarunkowania postępowania z odpadami w Polsce w okresie epidemii COVID-19²
}

Wpłyną: 19.10.2020. Akceptacja: 25.11.2021

\section{Streszczenie}

Przedmiotem artykułu jest analiza rozwiązań prawnych odnoszących się do zasad postępowania z odpadami medycznymi oraz komunalnymi pochodzącymi od osób objętych kwarantanną w okresie pandemii COVID-19 wraz z analizą wpływu określonych tam instrumentów na funkcjonujące rozwiązania legislacyjne i perspektywicznych skutków wprowadzenia tych regulacji. W artykule analizie poddano obowiązujący porządek prawny, jednocześnie wskazując zarówno na wyjątkowość zastosowanych instytucji prawnych (w kontekście poleceń wojewody wyłączających regulacje prawa miejscowego czy obowiązki ustawowe oraz umów określających sposób wykonywania powierzanych zadań publicznych), jak i wpływ tych regulacji na późniejsze prowadzenie przez instalacje zagospodarowania odpadów. Jednocześnie zasygnalizowano szereg problemów praktycznych, jakie mogą pojawić się w związku z zastosowaniem prawem przewidzianych rozwiązań.

Słowa kluczowe: odpady, COVID-19, pandemia.

1 Dr hab. Artur K. Modrzejewski - Wydział Prawa, Uniwersytet w Białymstoku (Polska); e-mail: a.modrzejewski@uwb.edu.pl; ORCID: 0000-0002-3849-4208.

2 Badania wykorzystane w artykule nie zostały sfinansowane przez żadną instytucję. 


\title{
ARTUR K. MODRZEJEWSKI
}

\section{The Legal Conditions of Waste Management in Poland during the COVID-19 Epidemic ${ }^{3}$}

\begin{abstract}
The subject of the article is an analysis of the legal solutions governing the principles of handling medical waste and municipal waste produced by people under quarantine during the COVID-19 pandemic together with an analysis of the impact of the instruments specified therein on the existing legislative solutions and the prospective effects of the adoption of these regulations. The paper analyses the current legal framework, highlighting the uniqueness of the legal institutions used (in the context of a province governor's orders excluding local law regulations or statutory obligations, and contracts specifying the manner of performance of public tasks entrusted), as well as the impact of these regulations on the subsequent operation of waste management facilities. At the same time, a number of practical problems that may arise in connection with the application of solutions provided under the existing law have been brought to light.
\end{abstract}

Keywords: waste, COVID-19, pandemic.

3 The research in this article has not been supported financially by any institution. 


\section{Wstęp}

Zgodnie z ustawą z dnia 5 grudnia 2008 r. o zapobieganiu oraz zwalczaniu zakażeń i chorób zakaźnych u ludzi stan zagrożenia epidemicznego to sytuacja prawna wprowadzona na danym obszarze w związku z ryzykiem wystąpienia epidemii $\mathrm{w}$ celu podjęcia określonych $\mathrm{w}$ ustawie działań zapobiegawczych ${ }^{4}$. Zgodnie z art. 46 ust. 2 ustawy o chorobach zakaźnych, jeżeli zagrożenie epidemiczne lub epidemia występuje na obszarze więcej niż jednego województwa, stan zagrożenia epidemicznego lub stan epidemii ogłasza i odwołuje, w drodze rozporządzenia, minister właściwy do spraw zdrowia w porozumieniu z ministrem właściwym do spraw administracji publicznej na wniosek Głównego Inspektora Sanitarnego. Jednocześnie $w$ rozporządzeniu takim określanych jest szereg elementów odnoszących się do szeroko pojętego życia publicznego ${ }^{5}$.

Dnia 20 marca 2020 r. na podstawie rozporządzenia Ministra Zdrowia z dnia 20 marca 2020 r. w sprawie ogłoszenia na obszarze Rzeczypospolitej Polskiej stanu epidemii ${ }^{6}$ wprowadzono stan epidemii.

Wraz z wydawaniem poszczególnych rozporządzeń wprowadzających ograniczenia, wydawane były akty rangi ustawowej, które regulowały materię postępowania z odpadami w okresie trwania epidemii. Przy tym w okresie epidemii w polskim systemie prawnym doszło do niespotykanej dotąd rewolucji w określaniu źródeł prawa. Podstawowym instrumentem stały się bowiem rozporządzenia - wprowadzające ograniczania i określone w nich nakazy?

Szereg rozwiązań wprowadzonych został na mocy ustawy z dnia 2 marca $2020 \mathrm{r}$. o szczególnych rozwiązaniach związanych z zapobieganiem, przeciwdziałaniem i zwalczaniem COVID-19, innych chorób zakaźnych oraz wywołanych nimi sytuacji

4 Rozporządzenie Ministra Zdrowia z dnia 13 marca 2020 r. w sprawie ogłoszenia na obszarze Rzeczypospolitej Polskiej stanu zagrożenia epidemicznego (Dz.U. poz. 433); Ustawa z dnia 5 grudnia 2008 r. o zapobieganiu oraz zwalczaniu zakażeń i chorób zakaźnych u ludzi, tekst jedn. Dz.U. z 2019 r., poz. 1239, art. 2 pkt. 23, dalej jako: „ustawa o chorobach zakaźnych”.

$5 \quad$ Art. 46 ust. 4 ustawy o chorobach zakaźnych.

6 Rozporządzenie Ministra Zdrowia z dnia 20 marca 2020 r. w sprawie ogłoszenia na obszarze Rzeczypospolitej Polskiej stanu epidemii (Dz.U. poz. 491 ze zm.).

$7 \quad$ Por. np. uchwałę TK z 2.03.1994 r., W 3/93, Dz.U. Nr 36, poz. 137; wyrok TK z 10.11.1998 r., K 39/97, LEX nr 34601, a także F. Morawski, Zakaz przemieszczania się w związku z pandemią COVID-19 w świetle konstytucyjnego prawa do poruszania się, „Przegląd Prawa Publicznego” 2020, 9, s. 7-17. 
kryzysowych ${ }^{8}$. Zmiany w tej ustawie dokonane zostały na mocy ustawy z dnia 16 kwietnia 2020 r. o szczególnych instrumentach wsparcia w związku z rozprzestrzenianiem się wirusa SARS-CoV-29 ${ }^{9}$ Szczególny problem uwidoczniony był z dwoma kategoriami odpadów, czyli odpadami medycznymi oraz odpadami komunalnymi pochodzącymi z miejsc objętych kwarantanną.

Przedmiotem artykułu jest analiza rozwiązań prawnych odnoszących się do zasad postępowania $\mathrm{z}$ odpadami $\mathrm{w}$ okresie pandemii wraz $\mathrm{z}$ analizą wpływu określonych tam instrumentów na funkcjonujące rozwiązania legislacyjne i, być może, perspektywiczne skutki wprowadzenia tych regulacji.

\section{Postępowanie z odpadami medycznymi o właściwościach zakaźnych}

Zgodnie z art. 11 a Ustawy o COVID-19 w przypadku braku na obszarze województwa technicznych i organizacyjnych możliwości unieszkodliwiania, zgodnie z obowiązującymi przepisami, odpadów medycznych o właściwościach zakaźnych wytworzonych w związku z przeciwdziałaniem COVID-19 wojewoda może wydać, w drodze decyzji administracyjnej, polecenie dotyczące gospodarowania tymi odpadami następującym podmiotom określonym w art. 11 ust. 1 i 2 tej ustawy. Katalog podmiotowy potencjalnych adresatów takiego polecenia ustalony został bardzo szeroko i zaliczyć do niego należy wszystkie generalnie organy administracji publicznej inne podmioty publiczne, ale, co ciekawe, również podmioty prywatne, prowadzące działalność w zakresie gospodarowania odpadami.

Polecenie podlega natychmiastowemu wykonaniu z chwilą jego doręczenia lub ogłoszenia oraz nie wymaga uzasadnienia. Ten tryb nie pozbawia całkowicie możliwości kwestionowania treści postanowienia w toku postępowania odwoławczego, czy też później przed sądem administracyjnym ${ }^{10}$. Szczególny charakter zleconego do wykonania obowiązku oraz fakt natychmiastowego jego wykonania mogą powodować jednak, że skorzystanie ze środków zaskarżenia będzie zbyt późne i nie powstrzyma potencjalnych negatywnych konsekwencji realizacji

8 Ustawa z dnia 2 marca 2020 r. o szczególnych rozwiązaniach związanych z zapobieganiem, przeciwdziałaniem i zwalczaniem COVID-19, innych chorób zakaźnych oraz wywołanych nimi sytuacji kryzysowych, Dz.U. z 2020 r., poz. 374, dalej jako: „Ustawa o COVID-19”.

9 Ustawa z dnia 16 kwietnia 2020 r. o szczególnych instrumentach wsparcia w związku z rozprzestrzenianiem się wirusa SARS-CoV-2. Dz.U. z 2020 r., poz. 695.

10 A. Wróbel, Art. 127. Prawo do odwołania, [w:] M. Jaśkowska, M. Wilbrandt-Gotowicz, A. Wróbel (red.), Kodeks postępowania administracyjnego. Komentarz, wyd. 8, LEX online 2020. 
polecenia. Tym bardziej, że wydane polecenie nie znosi odpowiedzialności przedsiębiorcy za naruszenie innych posiadanych decyzji i pozwoleń.

Konstrukcja prawna wydania polecenia zakłada, że wykonywanie zadań objętych poleceniami wydanymi w stosunku do przedsiębiorców następuje na podstawie umowy zawartej z przedsiębiorcą przez wskazanego w decyzji wojewodę - i jest finansowane ze środków budżetu państwa z części budżetowej, której dysponentem jest wojewoda. Prace związane z prowadzeniem przygotowań do realizacji zadań objętych poleceniami, mające charakter planistyczny są finansowane ze środków własnych przedsiębiorcy. W przypadku niezawarcia umowy zadania objęte poleceniami są wykonywane na podstawie decyzji.

Umowa staje się elementem współistniejącym, uzupełniającym konstrukcję władczego polecenia. Z punktu widzenia teoretyczno-prawnego umowa taka nosi cechy umowy administracyjnej ${ }^{11}$. Jedną ze stron takiej umowy będzie organ administracji publicznej, umowa zawierana miałby być w ramach realizacji zadań użyteczności publicznej. Ustawodawca nie wskazał elementów umowy. Zauważyć jednak należy, że jej rolą będzie doprecyzowanie zasad przekazywania odpadów oraz kwestii finansowych. Szczegóły trudno jest określić w jednostronnym akcie władczym, zwłaszcza jeśli proces określony w poleceniu odbiega do zwykłego zakresu postępowania, a jednocześnie wymaga współdziałania każdej ze stron. W ustawie nie wskazuje się przy tym, by np. polecenie miało odnosić się do warunków przygotowania do transportu i transportu tych odpadów. Można założyć, że elementy te powinny znaleźć odzwierciedlenie w umowie.

Prace związane z prowadzeniem przygotowań do realizacji zadań mające charakter planistyczny, są finansowane ze środków własnych przedsiębiorcy. Ustawodawca nie wyjaśnił, jakiego rodzaju działania zaliczyć należy do działań planistycznych. Nie sprecyzowano również, czy przedmiotowa umowa dotyczyła będzie kosztów następczych związanych z postępowaniem z odpadami określonymi w poleceniach wydanych na podst. art. 11a i Ustawy, takimi jak np. koszty zagospodarowania ubocznych produktów spalania.

Negatywnie do założeń umowy i prac przygotowawczych odniósł się m.in. Rzecznik Praw Obywatelskich, wskazując, że umowa nie rozstrzyga o tym, kto poniesie koszty prac przygotowawczych i co ma wchodzić w zakres tych prac ${ }^{12}$.

Ustawa nie wskazuje, w jaki sposób określone zostaną stawki związane z zagospodarowaniem odpadów medycznych o właściwościach zakaźnych, wytworzonych

11 Por. B. Jawroska-Dębska, Umowy we wspótczesnej administracji, [w:] J. Boć, L. Dziewięcka-Bokun (red.), Umowy w Administracji, Wrocław 2008, s. 13-29.

12 A. Bodnar, Tarcza 3.0. Opinia RPO dla Senatu, https://www.rpo.gov.pl/pl/content/koronawirus-i-tarcza-3-0-rpo-uwagi-dla-senatu, 4.05.2020, s. 29. 
w związku z przeciwdziałaniem COVID-19 - jako nieobjęte cennikiem zarządzającego instalacją. Przy tym jeśli okazałoby się, że stawki te nie zostaną uzgodnione pomiędzy stronami umowy, to i tak nie stoi to na przeszkodzie wydaniu polecenia.

Umowa mogłaby odnosić się do tego, w jaki sposób określone zostaną formy dostawy odpadów oraz kto poniesie koszty postępowania z tymi odpadami - w tym również te związane ze zmianą organizacji pracy instalacji w przypadku odpadów medycznych.

W przypadku wydania polecenia do zarządzającego instalacją skierowane zostaną odpady medyczne o właściwościach zakaźnych wytworzonych w związku z przeciwdziałaniem COVID-19. Wskazać przy tym należy na treść Rozporządzenia Ministra Zdrowia z dnia 7 grudnia 2001 r. w sprawie postępowania ze zwłokami i szczątkami ludzkimi ${ }^{13}$, gdzie w $§ 5$ a określa się szczegółowe zasady postępowania ze zwłokami osób zmarłych na chorobę wywołaną wirusem SARS-CoV-2 (COVID-19). Wskazuje się tam m.in. na zakres czynności dezynfekujących zarówno same zwłoki, jak i worek, w którym się znajdują. Czynności te w przypadku zgonu w szpitalu są wykonywane przez osoby zatrudnione przez szpital, a w przypadku zgonu poza szpitalem przez odpowiednio przeszkolone osoby zatrudnione w zakładach pogrzebowych. Osoby bezpośrednio zaangażowane w proces dekontaminacji ciała i jego otoczenia oraz przygotowania do przewozu zwłok zmarłego zakażonego wirusem SARS-CoV-2 oraz mające bezpośredni kontakt ze zwłokami są zabezpieczane w specjalistyczne środki ochrony indywidualnej.

Z formalnego punktu widzenia nie ma żadnej różnicy pomiędzy właściwościami zakaźnymi zwłok osoby zmarłej na chorobę wywołaną wirusem SARS-CoV-2 (COVID-19) a odpadami pochodzącymi ze szpitala, gdzie przebywają chorzy zakażeni koronawirusem. Oznacza to, że nie jest wystarczającym nakazanie przyjmowania odpadów medycznych przez podmiot do tego niededykowany, ale koniecznym byłoby uwzględnienie specyfiki tych odpadów zarówno w procesie ich odbioru, jak i np. ewentualnego magazynowania. Dodatkowo wskazać należy, że właściwości zakaźne wykazywać mogą również odpady komunalne pochodzące od osób zakażonych - o czym w dalszej części opracowania.

Niestety ustawodawca nie odniósł się do tego, czy wydane polecenie wojewody zawierało będzie szczegółowe wytyczne co do przygotowania odpadów do transportu czy zachowania określonych zasad bezpieczeństwa. Brak jest również jakichkolwiek regulacji odnoszących się do tego, w jaki sposób przeszkoleni będą pracownicy mający do czynienia z tego typu odpadami, w jaki sposób zapewnione zostaną im środki ochrony.

13 Rozporządzenie Ministra Zdrowia z dnia 7 grudnia 2001 r. w sprawie postępowania ze zwłokami i szczątkami ludzkimi, Dz.U. z 2001 r. Nr 153, poz. 1783. 
Unieszkodliwianie odpadów medycznych o właściwościach zakaźnych odbywać się ma przez termiczne przekształcanie rozumiane jako:

1) spalanie odpadów przez ich utlenianie w temperaturze nie niższej niż $850^{\circ} \mathrm{C}$;

2) inne, niż wskazany w pkt 1 , procesy termicznego przekształcania odpadów, $\mathrm{w}$ tym pirolizę, zgazowanie i proces plazmowy, o ile substancje powstające podczas tych procesów są następnie spalane.

Do gospodarowania odpadami medycznymi o właściwościach zakaźnych nie stosuje się przepisów ustawy z dnia 14 grudnia 2012 r. o odpadach ${ }^{14}-$ w zakresie w ustawie wskazanym oraz przepisów ustawy z dnia 27 kwietnia 2001 r. - Prawo ochrony środowiska ${ }^{15}$. Polecenie, można również wydać $w$ odniesieniu do podmiotu, który nie posiada decyzji z zakresu gospodarowania odpadami.

Wyłączenie zastosowania ustawy o odpadach oraz ustawy prawo ochrony środowiska, oznacza, że w tym zakresie wyłączone zostaną ograniczenia wprowadzone na danego przedsiębiorcę co do rodzaju przyjmowanych odpadów czy procesów technologicznych - wynikające np. z posiadanego pozwolenia zintegrowanego - założyć bowiem należy, że przedsiębiorca będący adresatem polecenia co do zasady nie ma uprawnienia do przyjmowania tego rodzaju odpadów medycznych. Wyłączone również będzie stosowanie rozporządzeń dotyczących postępowania $\mathrm{z}$ odpadami medycznymi ${ }^{16}$.

Opisana procedura nie tylko charakteryzuje się możliwością szybkiego działania przez organ administracji publicznej, ale co bardziej istotne, zakłada konieczność podejmowania działań z pominięciem możliwości prawnych zagospodarowania odpadów. Można również wskazać, że występuje tu widoczny prymat interesu ogólnego nad interesem przedsiębiorcy przyjmującego odpady do zagospodarowania $^{17}$.

Jednocześnie zastrzega się, że wydanie polecenia jest możliwe, jeżeli podmiot zobowiązany do gospodarowania odpadami posiada stosowne możliwości techniczne i organizacyjne do jego realizacji.

Zdaje się, że to zastrzeżenie utrudniać może realizację wydanego polecania, co więcej - poddaje w wątpliwość jego zasadność. Założyć bowiem należy, że adresat takiego polecenia, jako podmiot niededykowany do zagospodarowania

14 Ustawa z dnia 14 grudnia 2012 r. o odpadach, Dz.U. z 2019 r. poz. 701, ze zm.

15 Ustawa z dnia 27 kwietnia 2001 r. - Prawo ochrony środowiska, Dz.U. z 2019 r., poz. 1396 ze zm.

16 Rozporządzenie Ministra Zdrowia z dnia 5 października 2017 r. w sprawie szczegółowego sposobu postępowania z odpadami medycznymi, Dz.U. z 2017 r., poz. 1975; Rozporządzenie Ministra Zdrowia z dnia 21 października 2016 r. w sprawie wymagań i sposobów unieszkodliwiania odpadów medycznych i weterynaryjnych, Dz.U. z 2016 r., poz. 1819.

17 P. Korzeniowski, Bezpieczeństwo ekologiczne jako instytucja prawa ochrony środowiska, Łódź 2012, s. 317. 
odpadów medycznych, nie będzie mógł w większości przypadków spełnić warunków do ich zagospodarowania. Trudno jest przy tym określić, co miał na myśli ustawodawca, zakładając, że tego rodzaju podmiot musi posiadać możliwość techniczne do zagospodarowania tego rodzaju odpadów. Prowadzący działalność w zakresie zagospodarowania odpadów komunalnych nie będzie posiadał możliwości technicznych spalania odpadów medycznych. Widoczne to będzie nie tylko w zakresie spełnienia wymogów technicznych dla spalenia odpadów, ale również warunków do ich magazynowania. W zakresie magazynowania dodano ust. 9, zgodnie z którym polecenie może także dotyczyć magazynowania odpadów medycznych przez ich wytwórcę ${ }^{18}$.

Naruszenie wymogów gospodarowania odpadami wynikających z posiadanych decyzji - w związku z realizacją poleceń wojewody - może rodzić konsekwencje w postaci karania przedsiębiorców. Tutaj trzeba zastrzec, że wydaje się, iż nie można automatycznie przyjąć, że zawsze skuteczną linią obrony będzie powoływanie się na treść polecenia. Jeśli bowiem na skutek wykonywania poleceń wojewody przekroczone zostaną maksymalne wartości (czy to czasu pracy instalacji, czy ilości przyjmowanych odpadów), wówczas trudna do zaakceptowania byłaby interpretacja, że polecenie wojewody wyłącza zastosowanie elementów np. pozwolenia zintegrowanego. Wartości określone w pozwoleniu co do zasady mają bowiem charakter maksymalny i jako takie traktowane są przez organy kontrolne ${ }^{19}$. Być może w perspektywie karania zasadnym byłoby powoływanie się na art. 189e ustawy z dnia 14 czerwca 1960 r. - Kodeks postępowania administracyjnego ${ }^{20}$, na postawie którego - w przypadku gdy do naruszenia prawa doszło wskutek działania siły wyższej - strona nie podlega ukaraniu.

Na gruncie k.p.a., pojęcie siły wyższej nie zostało zdefiniowane, ale należy przyjąć, że przesłanką nałożenia administracyjnej kary pieniężnej powinno być wystąpienie subiektywnego elementu zawinienia ${ }^{21}$, a podmiot, który może być pociągnięty do odpowiedzialności, powinien mieć możliwość obrony, m.in. poprzez

18 Ustawa z dnia 16 kwietnia 2020 r. o szczególnych instrumentach wsparcia w związku z rozprzestrzenianiem się wirusa SARS-CoV-2. art. 73, pkt. 11 lit. b.

19 K. Gruszecki, Prawo ochrony środowiska. Komentarz, wyd. 5, Warszawa 2019, LEX online, Ministerstwo Środowiska, Wytyczne do sporzadzania wniosku o wydanie pozwolenia zintegrowanego, https://ekoportal.gov. pl/fileadmin/Ekoportal/Pozwolenia_zintegrowane/poradniki_branzowe/opracowania/Wytyczne_do_ sporzadzania_wniosku_o_wydanie_PZ.pdf (dostęp: 18.10.2020), s. 12.

20 Ustawa z dnia 14 czerwca 1960 r. - Kodeks postępowania administracyjnego, tekst jedn. Dz.U. z 2020 r., poz. 256 t.j., dalej „k.p.a.".

21 A. Wróbel, Komentarz do art. 189r Kpa, [w:] M. Jaśkowska, M. Wilbrandt-Gotowicz, A. Wróbel, Komentarz aktualizowany do Kodeksu postępowania administracyjnego, LEX/el. 2020; W. Warkałło, Sita wyższa jako zasada nieodpowiedzialności i domniemanie przypadkowości szkody, „Państwo i Prawo” 1949, 9-10, s. 100-102. 
wykazanie, że naruszenie jest następstwem okoliczności, na które nie miał wpływu $\mathbf{u}^{22}$. Zdecydowanie prowadzący instalację nie ma wpływu zarówno na sam fakt stanu epidemii, jak i na konsekwencje z tym związane - w postaci wydanego polecenia.

Tak uregulowany stan prawny rodzi kolejne pytania o to, czy określone w art. 11a ust. 3 Ustawy wyłączenie zastosowania u.o. - w zakresie warunków transportu odpadów, zbierania odpadów lub ich unieszkodliwiania oraz przepisów p.o.ś., w zakresie warunków korzystania ze środowiska - zwalnia zarządzającego instalacją z odpowiedzialności i ewentualnych sankcji związanych z mogącymi zaistnieć nieprawidłowościami np. w zakresie czasu magazynowania, wymogów technicznych pomieszczenia do magazynowania oraz wymagań odnoszących się do zabezpieczenia osób przebywających w takim pomieszczeniu? Czy wydanie polecenia na podst. art. 11a Ustawy zwalnia z obowiązku dotyczącego dokumentowania skuteczności procesu unieszkodliwiania odpadów pod kątem utraty właściwości zakaźnych w drodze stosownych badań? Należy podkreślić, że z założenia instalacja będąca adresatem polecenia wojewody nie będzie przeznaczona do tego rodzaju odpadów i nawet przy zachowaniu najwyższej staranności mogą zaistnieć nieprawidłowości związane z wykonaniem polecenia wojewody.

Ustawodawca nie odniósł się również do tego, w jaki sposób polecenie wojewody wydanie na podst. art. 11a Ustawy wypływać ma na inne posiadane przez zarządzającego instalacją decyzje niepozwalające na przyjmowanie odpadów medycznych np. inne koncesje.

W zakresie obowiązków ewidencyjnych zakłada się, że do prowadzenia ewidencji odpadów w przypadku wydania przez wojewodę polecenia podmiotowi, który nie ma możliwości prowadzenia tej ewidencji za pośrednictwem BDO, stosuje się odpowiednio art. 67 ust. 7, 9, 12 i 14 u.o. - zakłada się prowadzenie ewidencji bądź to $\mathrm{w}$ formie papierowej, bądź elektronicznej poza bazą. Analogicznie również transportujący będzie zobowiązany do posiadania karty przekazania odpadów $\mathrm{w}$ formie papierowej. Dopuszczenie papierowej wersji karty przekazania odpadów i prowadzenia ewidencji podsystemem mimo wszystko może stwarzać pole do licznych nadużyć. Podmiot, który nie ma możliwości prowadzenia ewidencji odpadów za pośrednictwem BDO, a który dokonał unieszkodliwienia odpadów na podstawie polecenia wojewody, przekazuje kopię karty ewidencji odpadów właściwemu ze względu na miejsce unieszkodliwienia odpadów wojewódzkiemu inspektorowi ochrony środowiska w terminie 14 dni od dnia unieszkodliwienia odpadów.

Opisana procedura charakteryzuje się zarówno znacznym stopniem wyjątkowości - względem normalnie określonych zasad postępowania z odpadami medycz-

22 S. Dudziak, Zasady wymiaru administracyjnych kar pieniężnych po nowelizacji Kodeksu postępowania administracyjnego, „Samorząd Terytorialny” 2018, 6, s. 23. 
nymi, ale także niestety rodzi wątpliwości interpretacyjne. Ustawodawca nie wyjaśnia, czy przedmiotowy strumień odpadów medycznych o właściwościach zakaźnych wytworzonych w związku z przeciwdziałaniem COVID-19 po zakończeniu stanu epidemii lub obowiązywania polecenia wojewody zostanie wliczony do maksymalnego rocznego strumienia odpadów dopuszczonego np. w pozwoleniu zintegrowanym wydanym dla instalacji? Brak jest również informacji co do wliczenia tego strumienia do poziomów odzysku oraz wpływu tego strumienia na ewentualne sankcje za brak uzyskania takich poziomów.

Można przyjąć, że skoro polecenie jest wyjątkiem do ogólnie przyjętych zasad i regul, zgodnie z zasadą exceptiones non sunt extendendae $e^{23}$, to, o ile nie przewiduje określonych odstępstw w zakresie realizacji dotychczasowych pozwolen, wykonywanie działalności określonej w poleceniu będzie wywierało bezpośredni wpływ na inne posiadane przez instalację decyzje (masa przetworzonych odpadów wliczana powinna być do masy odpadów dopuszczonych do przetworzenia na podstawie posiadanych decyzji). Przekroczenie określonych w pozwoleniach limitów - np. względem określonego w innych decyzjach czasu pracy instalacji czy masy odpadów przyjętych do przetworzenia, rodzić też może sankcje po stronie przedsiębiorcy. Ewentualnie możliwym byłoby powoływanie się na zaistnienie przesłanki siły wyższej, tu jednak pozostaje ryzyko uznaniowej interpretacji ze strony organów administracji.

\section{Postępowanie z odpadami innymi, w tym odpadami komunalnymi}

Odrębny tryb postępowania Ustawa przewiduje w zakresie odpadów komunalnych ${ }^{24}$ wytworzonych w trakcie zarządzonej kwarantanny.

Zgodnie z art. 11 b Ustawy w przypadku braku na obszarze województwa technicznych i organizacyjnych możliwości unieszkodliwiania zgodnie z obowiązującymi przepisami odpadów wytwarzanych w związku z przeciwdziałaniem COVID-19 innych niż odpady medyczne o właściwościach zakaźnych, wojewoda może wydać, w drodze decyzji administracyjnej, polecenie dotyczące gospodarowania tymi odpadami podmiotom, o których mowa w art. 11 ust. 1 i 2 . Polecenie podlega natychmiastowemu wykonaniu z chwilą jego doręczenia lub ogłoszenia oraz nie wymaga uzasadnienia. Tu również przewiduje się konieczność wcześniej-

\footnotetext{
23 J. Wróblewski, Interpretatio Extensiva, „Ruch Prawniczy, Ekonomiczny i Socjologiczny” 1965, 27(1), s. 112-114.

24 Wyrok Sądu Apelacyjnego w Gdańsku z dnia 27 września 2017 r., sygn. I ACa 1201/16, LEX nr 2446575.
} 
szego podjęcia działań w kierunku unormowania wzajemnych relacji na gruncie umownym.

W przypadku odpadów komunalnych polecenie wojewody może także dotyczyć:

1) przekazywania niesegregowanych (zmieszanych) odpadów komunalnych do innych instalacji niż instalacje komunalne zapewniające mechaniczno-biologiczne przetwarzanie niesegregowanych (zmieszanych) odpadów komunalnych i wydzielanie z niesegregowanych (zmieszanych) odpadów komunalnych frakcji nadających się w całości lub w części do odzysku;

2) składowania lub termicznego przekształcania odpadów komunalnych bez (jakichkolwiek lub określonych) wstępnych procesów przetwarzania.

Zastanowić się można, czy odpady wskazane w poleceniach wojewody (na podst. art. 11a i 11b Ustawy) będą miały priorytet $w$ stosunku do pozostałych strumieni w przypadku, gdy wydajność dobowa/roczna instalacji nie będzie pozwalała na przyjęcie do zagospodarowania każdego rodzaju dostarczanych odpadów? Ustawodawca wprost nie przewiduje takiego priorytetowego traktowania, z drugiej strony wyjątkowość sytuacji, jak i szczególny rygor wydania decyzji nakazuje przyjąć, że odpady te mogą mieć pierwszeństwo ${ }^{25}$.

W przypadku wydania polecenia wojewody na podst. art. 11a Ustawy konsekwencją może być przekierowanie strumienia niesegregowanych (zmieszanych) odpadów na pole składowe zarządzającego instalacją, co z kolei spowodować może przekroczenie limitów określonych w pozwoleniu zintegrowanym. W takiej sytuacji konieczne może być zwrócenie się do wojewody celem wydania polecenia na podst. art. 11b Ustawy i określenia sposobu postępowania z odpadami wytwarzanymi w związku z przeciwdziałaniem COVID-19 innymi niż odpady medyczne o właściwościach zakaźnych (stanowiących zgodnie z Wytycznymi odpady komunalne), tj. przekazanie odpadów do innych instalacji niż instalacje komunalne zapewniające przetwarzanie, o którym mowa w art. 35 ust. 6 pkt 1 ustawy z dnia 14 grudnia 2012 r. o odpadach. W takim przypadku zarządzający instalacją nie będzie mógł samodzielnie zadecydować o sposobie postępowania z tymi odpadami, nawet przy założeniu przekroczenia określonych pozwoleniem zintegrowanym limitów. Skoro bowiem istnieją instrumenty prawne do określenia pewnego postępowania ze strumieniem odpadów, nadinterpretacją byłoby dopuszczenie, że prowadzący instalację może samodzielnie podejmować pewne działania.

Część wątpliwości odnoszących się do zasad postępowania z odpadami pochodzącymi z kwarantanny określonych zostało w niewiążących wytycznych Ministra

25 Na problemy związane z wykonaniem polecenia wojewody zwraca uwagę M. Bursztynowicz, Gospodarowanie odpadami w czasie epidemii, LEX - online 2020. 
Klimatu i Głównego Inspektora Sanitarnego w sprawie postępowania z odpadami wytwarzanymi w czasie występowania zakażeń koronawirusem SARS-CoV-2 i zachorowań na wywoływaną przez niego chorobę COVID-19 (w czasie trwania pandemii/epidemii) ${ }^{26}$.

Wytyczne z założenia odnoszą się do odpadów wytworzonych przez osoby, które były narażone na zakażenie koronawirusem SARS-CoV-2, mają bezpośredni kontakt z osobami zakażonymi koronawirusem SARS-CoV-2, chorych na COVID-19. Już nawet zakres osób wytwarzających odpady objęty Wytycznymi jest nieprecyzyjny, zauważyć bowiem należy, że osoba zakażona koronawirusem może nie mieć wiedzy o tym, że jest nosicielem, tym bardziej osoba, która miała styczność z zakażonym może nie wiedzieć, kiedy i czy w ogóle miały styczność z osobą chorą. W praktyce oznacza to, że by Wytyczne miały jakikolwiek sens prewencyjny, powinny odnosić się do całego strumienia odpadów komunalnych wytwarzanych w czasie epidemii.

Wytyczne jednoznacznie stwierdzają, że odpady wytwarzane w miejscach kwarantanny lub izolacji ze względu na miejsce powstawania oraz na ich skład stanowią odpady komunalne. Jednakże z uwagi na świadomość, że odpady te wytwarzane będą przez osoby zakażone wirusem SARS-CV-2 lub chore na COVID-19 oraz brak potwierdzonych ustaleń naukowych, co do czasu aktywności koronawirusa na powierzchniach różnych materiałów wchodzących w skład odpadu, należy z tymi odpadami postępować przy zachowaniu szczególnych środków ostrożności. Jak najbardziej aktualność zachowują tu uwagi poczynione w kontekście postępowania z odpadami w świetle Rozporządzenia Ministra Zdrowia z dnia 7 grudnia 2001 r. w sprawie postępowania ze zwłokami i szczątkami ludzkimi. Skoro w większości przypadków nie wiadomo, z którego gospodarstwa domowego pochodzić mogą odpady zakażone wirusem, a jednocześnie niewątpliwie przyjmuje się szczególne zasady postępowania z odpadami zawierającymi szczątki organiczne, to, być może, jedynym racjonalnym i bezpiecznym wyjściem byłoby faktycznie uznanie, że w okresie epidemii wszystkie odpady noszą potencjalne ryzyko zarażenia i powinny zostać w sposób szczególny zagospodarowane. Uzasadnione wydaje się również czasowe zrezygnowanie z selektywnej zbiórki i ze składowania tych odpadów - nadając priorytet ich spalaniu.

26 Wytyczne Ministra Klimatu i Głównego Inspektora Sanitarnego w sprawie postępowania z odpadami wytwarzanymi w czasie występowania zakażeń koronawirusem SARS-CoV-2 i zachorowań na wywoływaną przez niego chorobę COVID-19 (w czasie trwania pandemii/epidemii), file:///C:/Users/user/ Downloads/Wytyczne_dot_post\%C4\%99powania_z_odpadami_w_czasie_wyst\%C4\%99powania_zaka\%C5\%BCe\%C5\%84_koronawirusem_SARS-CoV-2-2.pdf (dostępp: 12.05.2020). 
W kontekście wyodrębniania strumienia odpadów pochodzących z gospodarstw domowych, gdzie mogą przebywać osoby zakażone wirusem, kluczowa wydaje się kwestia wskazania adresów osób przebywających w kwarantannie.

Dysponentami informacji o adresach osób przebywających w izolacji i kwarantannie są wojewodowie, policja i ośrodki pomocy społecznej. Dane te nie mogą być co do zasady przekazywane przez dysponentów innym podmiotom ${ }^{27}$. Wytyczne zalecają, by podejmować działania w porozumieniu z wojewodami, policją, czy ośrodkami pomocy społecznej - w miarę możliwości zapewniać worki w określonym kolorze i/albo oznaczonych symbolem (np. napisem „C' $\mathrm{C}^{\prime}$, w celu jednoznacznej identyfikacji odpadów z gospodarstw domowych lub od osób z grup ryzyka. Ten sposób identyfikacji worków powoduje jednak, że bardzo łatwo będzie wskazać miejsca, gdzie przebywają osoby w kwarantannie (czyli nie koniecznie chore). Co może prowadzić do nieuzasadnionego ujawnienia miejsca ich przebywania. Próby upubliczniania adresów, pod którymi przebywały osoby poddawane kwarantannie, spotykały się z krytyką i sprzeciwem - zarówno społecznym, jaki zainteresowanych organów ${ }^{28}$.

W przypadku takich nieruchomości Wytyczne zakładają zapewnienie odbioru nie rzadziej niż co 7 dni worków, zorganizowanie odpowiedniego transportu, bezpośrednio do instalacji unieszkodliwiania odpadów komunalnych worków, lub wyznaczonych przez gminę miejsc zbierania odpadów komunalnych z gospodarstw domowych objętych izolacją. Zapewnienie dezynfekcji pojemników wielokrotnego użytku oraz środków transportu odpadów z gospodarstw domowych lub od osób.

Co istotne, minimalną częstotliwość odbioru określonych frakcji odpadów reguluje ustawa z dnia 13 września 1996 r. o utrzymaniu czystości i porządku w gminach $^{29}$. Zasadą jest, iż harmonogram odbioru odpadów określony jest w każdej gminie na podstawie regulaminu utrzymania czystości i porządku w gminie i szczegółowego zakresu świadczenia usług - czyli aktów prawa miejscowego. Wytyczne nie stanowią źródła prawa powszechnie obowiązującego - nie mogą w żadnym zakresie podważać ustaleń zawartych w aktach rangi ustawowej czy aktach prawa miejscowego ${ }^{30}$. Odrębną kwestią jest koszt wykonywania takiej usługi - odbiega-

27 A. Jelinek, Przewodnicząca Europejskiej Rady Ochrony Danych, Oświadczenie w sprawie przetwarzania danych osobowych w kontekście pandemii COVID-19 przyjęte w dniu 19 marca 2020 r., https://uodo. gov.pl/pl/138/1463 (dostęp: 13.05.2020).

28 https://www.rpo.gov.pl/pl/content/koronawirus-starosta-wysokomazowiecki-nie-mial-na-myslistygmatyzowania-chorych (dostęp: 19.05.2020).

29 Ustawa z dnia 13 września 1996 r. o utrzymaniu czystości i porządku w gminach, tekst jedn. Dz.U. z 2019 r., poz. 2010, dalej jako: „u.c.p.g.”.

30 W. Płowiec, Koncepcja aktu prawa wewnętrznego w Konstytucji RP, Poznań 2006, s. 47. 
jącej od normalnego harmonogramu wynikającego ze wskazanych aktów prawa miejscowego, a także od warunków określonych w umowie na odbiór odpadów.

Do zmiany częstotliwości odbioru odpadów odnosi się art. 11 Ustawy, zgodnie z którym wojewoda może, w drodze zarządzenia, zmienić lub wyłączyć wymagania dotyczące selektywnego zbierania odpadów komunalnych określone w regulaminie utrzymania czystości i porządku w gminie oraz w przepisach wydanych na podstawie art. 4 a ust. 1 u.c.p.g.

W zarządzeniu wojewoda może także, na wniosek wójta, burmistrza albo prezydenta miasta, zmienić częstotliwość odbierania odpadów komunalnych oraz sposób świadczenia usług przez punkty selektywnego zbierania odpadów komunalnych określone w uchwałach rady gminy wydanych na podstawie przepisów ustawy z dnia 13 września 1996 r. o utrzymaniu czystości i porządku w gminie.

W przypadku wydania zarządzenia na obszarze województwa lub jego części, których zarządzenie dotyczy, nie stosuje się wymagań dotyczących selektywnego zbierania odpadów komunalnych określonych w u.c.p.g. W ten sposób zarządzenie wojewody deroguje niejako czasowo regulacje zawarte w aktach prawa miejscowego - co już samo w sobie jest rozwiązaniem szczególnym w kontekście przyznanych wojewodzie uprawnień odnoszących się do nadzoru nad gospodarką odpadami komunalnymi ${ }^{31}$.

Oznacza to, że wymagania określone przez wojewodę będą miały pierwszeństwo przed normami ustawowymi i wyłączają zastosowanie wszystkich przepisów ustawy o utrzymaniu czystości i porządku w gminach dotyczących wymagań dla selektywnego zbierania odpadów komunalnych niezależnie od zakresu, w jakim wojewoda wydał zarządzenie ${ }^{32}$. Stanowi to całkowite odwrócenie hierarchii źródeł prawa w obliczu sytuacji wyjątkowej spowodowanej pandemią.

W uzasadnieniu do rządowego projektu ustawy o zmianie ustawy o szczególnych rozwiązaniach związanych z zapobieganiem, przeciwdziałaniem i zwalczaniem COVID-19, czytamy, że: „W związku z zagrożeniem, jakie mogą stanowić odpady wytwarzane w gospodarstwach domowych, ważne jest również, aby zastosowana została odpowiednia częstotliwość odbierania odpadów komunalnych. Najlepiej wiedzą o potrzebach w tym zakresie wójtowie, burmistrzowie i prezydenci miast, dlatego będą mogli zawnioskować do wojewody o zmiany w tym zakresie"33.

\footnotetext{
31 A.K. Modrzejewski, Nadzór RIO i wojewodów nad czystością i porządkiem w gminach, „Kontrola Państwowa” 2014, 3, s. 119-129.

32 M. Bursztynowicz, Uchwały śmieciowe w czasie epidemii koronawirusa, LEX - online 2020.

33 Uzasadnienie projektu ustawy, IX kadencja, druk sejm. nr 299, s. 7.
} 
Przykładem wykorzystania tej regulacji jest zarządzenie wojewody małopolskiego z 3 kwietnia 2020 r. ${ }^{34}$, w którym nie zwiększono, ale właśnie zmniejszono częstotliwość odbierania odpadów komunalnych (co z kolei jest rekomendowane w Wytycznych). Postanowieniami zarządzenia zmieniono zapis Regulaminu utrzymania czystości i porządku na terenie Miasta i Gminy Myślenice w ten sposób, że wywóz worków na papier, tekturę, tworzywa sztuczne, odpady opakowaniowe wielomateriałowe i metale dla budynków jednorodzinnych zlokalizowanych na terenie Miasta i Gminy Myślenice odbywał się w okresie od 1.04.2020 r. do 31.05.2020 r. nie rzadziej niż co 4 tygodnie (wcześniej odbiór miał miejsce nie rzadziej niż co 2 tygodnie).

Wytyczne szczegółowo opisują proces pozbycia się odpadów. Zakłada się, że magazynowanie odpadów w miejscach przeznaczonych do gromadzenia odpadów, z wyłączeniem zabudowy jednorodzinnej, prowadzi się w zamykanych pojemnikach lub kontenerach oznakowanych w sposób zabezpieczający przed rozprzestrzenianiem odpadów, zabezpieczonych przed dostępem osób postronnych oraz zwierząt.

Wytyczne przewidują także, że odpady, zgodnie z wstępnymi wytycznymi Komisji Europejskiej ${ }^{35}$, po 9 dniach przestają stanowić zagrożenie. Jeżeli worek z odpadami pochodzącymi z kwarantanny jest rozerwany lub niezamknięty, odbierający odpady powinien w miarę możliwości poinformować osobę, która worek wystawiła (np. przez umieszczenie kartki na drzwiach), o konieczności szczelnego zamykania odpadów.

Zaleca się, aby odpady selektywnie zebrane były w miarę możliwości magazynowane przez 9 dni przed skierowaniem ich do przetworzenia. Odpady w workach nie powinny być przetwarzane z udziałem osób sortujących - w przypadku braku możliwości technicznych przetwarzania wyłącznie na liniach całkowicie zautomatyzowanych bez udziału człowieka, odpady należy kierować bezpośrednio do unieszkodliwiania (zaleca się termiczne przekształcanie lub bezpośrednie składowanie najlepiej na składowiskach z instalacją do aktywnego odgazowania).

W przypadku niedoboru personelu w świadczeniu usług odbierania lub zagospodarowywania odpadów zaleca się: zmniejszenie częstotliwości odbioru selektywnie zebranych odpadów z frakcji szkła, papieru, metali i tworzyw sztucznych,

34 Zarządzenie Wojewody Małopolskiego, nr poz. rej. 142/20 z 3.04.2020 r. w sprawie zmiany częstotliwości odbierania wybranych frakcji odpadów komunalnych na terenie Miasta i Gminy Myślenice, Dz. Urz. Małop. poz. 2701.

35 Waste management in the context of the coronavirus crisis, https://ec.europa.eu/info/files/waste-management-context-coronavirus-crisis_en (dostęp: 19.05.2020). 
zapewnienie w pierwszej kolejności przetwarzania zmieszanych odpadów komunalnych i bioodpadów.

Wytyczne nie stanowią prawa powszechnie obowiązującego, skąd więc należy wywodzić podstawę prawną do ustalenia hierarchii w przyjmowaniu określonych kategorii odpadów? Należy przy tym zauważyć, że nawet Wytyczne nie odnoszą się do zakaźnych odpadów medycznych, o których mowa w art. 11a Ustawy, co oznacza, że w tym zakresie brak jest nawet rekomendacji co do hierarchii przyjmowania do zagospodarowania tych odpadów.

Powyższe regulacje prawne poddane zostały modyfikacjom na gruncie ustawy z dnia 14 maja 2020 r. o zmianie niektórych ustaw w zakresie działań osłonowych w związku z rozprzestrzenianiem się wirusa SARS-CoV-2 ${ }^{36}$ - nazywanej „Tarczą antykryzysową 3.0".

Na etapie prac nad tą ustawą RPO krytycznie ocenił odesłanie w zakresie kosztów planistycznych dla przedsiębiorcy, przede wszystkim w kontekście szerokiego zakresu pojęcia gospodarowania odpadami.

Rzecznik wskazywał, że w jego ocenie należy spodziewać się wydawania poleceń przez wojewodę, gdy ilość i rodzaj odpadów przekroczy istniejące możliwości zakładów (art. 11a i art. 11b Ustawy), będzie się wiązać z tym pośpiech, gdyż co do zasady ma to następować w sytuacjach nagłych. Nie można więc wykluczyć błędów w zakresie ustalenia ww. możliwości technicznych i organizacyjnych. Przedsiębiorcy będą więc zmuszeni do zbadania tych możliwości we własnym zakresie, co może oznaczać konieczność zatrudnienia specjalisty, zlecenia opinii technicznej etc. Prace planistyczne mogą polegać także na opracowaniu przez przedsiębiorcę logistyki zagospodarowania odpadów, w tym np. współpracy z firmami transportowymi. Trudno przewidzieć, jakie ilości odpadów staną się przedmiotem poleceń, lecz mając na uwadze podstawową przesłankę z art. 11a i 11b - czyli brak na obszarze województwa technicznych i organizacyjnych możliwości unieszkodliwiania - mogą być to ilości znaczne. Co za tym idzie, wspomniane tytułem przykładu koszty badań technicznych czy logistycznych również mogą być wysokie. Wówczas obciążanie tymi kosztami będzie dla przedsiębiorców krzywdzące ${ }^{37}$.

\footnotetext{
36 Ustawa z dnia 14 maja 2020 r. o zmianie niektórych ustaw w zakresie działań osłonowych w związku z rozprzestrzenianiem się wirusa SARS-CoV-2, Dz.U. z 2020 r., poz. 875.

37 A. Bodnar, op. cit., s. 29.
} 


\section{Zakończenie}

Oprócz podnoszonych powyżej wątpliwości, związanych czy to z wydawaniem przez wojewodę poleceń, czy określonych zarządzeń, pojawiają się inne istotne pytania praktyczne - na które w znacznej mierze nie da się udzielić jednoznacznej odpowiedzi.

Czy przykładowo w przy padku wydania poleceń, o których mowa w art. 11a i 11b Ustawy, możliwe będzie następcze wydobycie ze składowiska i np. przekształcenie termiczne niesegregowanych (zmieszanych) odpadów komunalnych, które przekazane zostały do składowania, czy to jako konsekwencja udzielenia pierwszeństwa termicznemu przekształceniu odpadów medycznych o właściwościach zakaźnych wytworzonych w związku z przeciwdziałaniem COVID-19, bądź odpadów wytwarzanych w związku z przeciwdziałaniem COVID-19 innych niż odpady medyczne o właściwościach zakaźnych? Ewentualnie zostały one skierowane do składowania bez (jakichkolwiek lub określonych) wstępnych procesów przetwarzania - na podstawie art. 11b ust. 2 pkt. 2 Ustawy. Zgodnie z art. 145 ust. 1 u.o. zakazane jest przecież wydobywanie odpadów ze składowiska odpadów, na którym są składowane niesegregowane (zmieszane) odpady komunalne lub niesegregowane (zmieszane) odpady komunalne z innymi rodzajami odpadów.

Czy po ustaniu stanu epidemii lub obowiązywania polecenia wojewody możliwe będzie nałożenie na zarządzającego zakładem opłaty podwyższonej za przekroczenie wyżej wymienionego limitu na 2020 r.?

Czy wydanie stosownego polecenia i skierowanie do spalarni odpadów, o których mowa w art. 11 a i 11b Ustawy, a przez to niemożność termicznego przekształcania odpadów stanowiących tzw. "frakcję wysokokaloryczną" - która nie może być składowana i przekierowania jej na pole składowe - wyłącza możliwość sankcjonowania niedozwolonego składowania odpadów o kodzie 19 12 12, 191210 ?

W jaki sposób postępować z popiołami i żużlami powstałymi w procesie termicznego przekształcania odpadów medycznych o właściwościach zakaźnych wytworzonych w związku z przeciwdziałaniem COVID-19 oraz odpadów wytwarzanych w związku z przeciwdziałaniem COVID-19 innych niż odpady medyczne o właściwościach zakaźnych?

Wszelkie próby udzielenia odpowiedzi na powyższe pytania pozostają jedynie w sferze skomplikowanych interpretacji - przekraczających pojemność niniejszego tekstu, ale - w mojej ocenie - zawsze trzeba przyjmować ścieżkę postępowania ostrożnościową. To znaczy koniecznym jest przyjęcie, że nic poza tym, co zostanie opisane w umowie, jak i tym, co nakazuje wydane polecenie bądź zarządzenie, nie będzie interpretowane rozszerzająco i na korzyść prowadzącego instalację. Tego rodzaju interpretacji nie będą stosowały organy administracji, które dla podejmo- 
wania określonych działań wymagają bezpośredniej podstawy prawnej, a tej ustawa szczególna nie wprowadza. Ustawa zdecydowanie daje prymat interesowi ogólnemu, jakim będzie konieczność zagospodarowania odpadów powstałych w okresie pandemii, nie przewidując instrumentów prawnych chroniących na przyszłość podmioty zagospodarowujące te odpady.

W perspektywie czasowej rozważyć należy wprowadzenie możliwości okresowej rezygnacji z prowadzenia selektywnej zbiórki odpadów i uznanie, że wszystkie niesegregowane (zmieszane) odpady komunalne pochodzące z terenu gminy stanowią potencjalne źródło zakażenia, przez co powinno się zachować szczególny rygor postępowania z nimi, z możliwością przekazywania niesegregowanych (zmieszanych) odpadów komunalnych do innych instalacji niż instalacje komunalne zapewniające przetwarzanie, o którym mowa w art. 35 ust. 6 pkt 1 u.o. - składowanie lub termiczne przekształcanie odpadów komunalnych bez (jakichkolwiek lub określonych) wstępnych procesów przetwarzania.

Zasadne byłoby bezpośrednie wskazanie, że wprowadzone nadzwyczajne rygory powiązane z wydaniem poleceń, o których mowa w art. 11a i 11b Ustawy, oraz ewentualnego zarządzenia wydanego na podstawie art. 11c, wyłączają ograniczenia związane z posiadanymi przez zarządzającego instalację zezwoleniami oraz wyłączają ewentualne sankcje będące konsekwencją potencjalnych naruszeń zasad określonych w tych zezwoleniach, a także wyłączają inne zobowiązania nałożone na zarządzającego instalacją, w tym m.in. termiczne przekształcanie frakcji wysokokalorycznej.

Należy wziąć pod uwagę zasadność bezpośredniego wskazania, że wprowadzone nadzwyczajne rygory powiązane $\mathrm{z}$ wydaniem polecen, o których mowa w art. 11a, wyłączają obowiązki zarządzającego instalacją związane z prowadzeniem odpowiednich badań, czy też obowiązki i ograniczenia wprowadzone w innych posiadanych zezwoleniach. Konieczne jest również uwzględnienie odpowiedniego podziału kosztów i możliwości dochodzenia zwrotu kosztów poniesionych na etapie prac przygotowawczych.

\section{Bibliografia}

\section{Literatura}

Bodnar A., Tarcza 3.0. Opinia RPO dla Senatu, https://www.rpo.gov.pl/pl/content/koronawirus-i-tarcza-3-0-rpo-uwagi-dla-senatu, 04.05.2020 (dostęp: 12.05.2020).

Bursztynowicz M., Gospodarowanie odpadami w czasie epidemii, LEX online 2020.

Bursztynowicz M., Uchwaty śmieciowe w czasie epidemii koronawirusa, LEX online 2020.

Dudziak S., Zasady wymiaru administracyjnych kar pieniężnych po nowelizacji Kodeksu postępowania administracyjnego, "Samorząd Terytorialny" 2018, 6. 
Gruszecki K., Prawo ochrony środowiska. Komentarz, wyd. 5, Warszawa 2019, LEX online. Jawroska-Dębska B., Umowy we wspótczesnej administracji, [w:] J. Boć, L. Dziewięcka-Bokun (red.), Umowy w Administracji, Wrocław 2008.

Jelinek A., Przewodnicząca Europejskiej Rady Ochrony Danych, Oświadczenie w sprawie przetwarzania danych osobowych w kontekście pandemii COVID-19 przyjęte w dniu 19 marca 2020 r., https://uodo.gov.pl/pl/138/1463 (dostęp: 13.05.2020).

Korzeniowski P., Bezpieczeństwo ekologiczne jako instytucja prawa ochrony środowiska, Łódź 2012.

Modrzejewski A.K., Nadzór RIO i wojewodów nad czystościq i porządkiem w gminach, „Kontrola Państwowa” 2014, 3.

Morawski F., Zakaz przemieszczania się w zwiazku z pandemia COVID-19 w świetle konstytucyjnego prawa do poruszania się, „Przegląd Prawa Publicznego” 2020, 9.

Płowiec W., Koncepcja aktu prawa wewnętrznego w Konstytucji RP, Poznań 2006.

Warkałło W., Sita wyższa jako zasada nieodpowiedzialności i domniemanie przypadkowości szkody, „Państwo i Prawo" 1949, 9-10.

Wróbel A., Art. 127. Prawo do odwołania, [w:] M. Jaśkowska, M. Wilbrandt-Gotowicz, A. Wróbel (red.), Kodeks postępowania administracyjnego. Komentarz, wyd. 8, LEX online 2020.

Wróbel A., Komentarz do art. 189r Kpa, [w:] M. Jaśkowska, M. Wilbrandt-Gotowicz, A. Wróbel, Komentarz aktualizowany do Kodeksu postępowania administracyjnego, LEX/ el. 2020.

Wróblewski J., Interpretatio Extensiva, „Ruch Prawniczy, Ekonomiczny i Socjologiczny” 1965, 27(1).

\section{Akty prawne}

Ustawa z dnia 14 czerwca 1960 r. - Kodeks postępowania administracyjnego, tekst jedn. Dz.U. z 2020 r., poz. 256.

Ustawa z dnia 13 września 1996 r. o utrzymaniu czystości i porządku w gminach, tekst jedn. Dz.U. z 2019 r., poz. 2010.

Ustawa z dnia 27 kwietnia 2001 r. - Prawo ochrony środowiska, Dz.U. z 2019 r., poz. 1396 ze zm.

Ustawa z dnia 5 grudnia 2008 r. o zapobieganiu oraz zwalczaniu zakażeń i chorób zakaźnych u ludzi, tekst jedn. Dz.U. z 2019 r., poz. 1239.

Ustawa z dnia 14 grudnia 2012 r. o odpadach, Dz.U. z 2019 r., poz. 701 ze zm.

Ustawa z dnia 2 marca 2020 r. o szczególnych rozwiązaniach związanych z zapobieganiem, przeciwdziałaniem i zwalczaniem COVID-19, innych chorób zakaźnych oraz wywołanych nimi sytuacji kryzysowych, Dz.U. z 2020 r., poz. 374.

Ustawa z dnia 16 kwietnia 2020 r. o szczególnych instrumentach wsparcia w związku z rozprzestrzenianiem się wirusa SARS-CoV-2, Dz.U. z 2020 r., poz. 695.

Ustawa z dnia 14 maja 2020 r. o zmianie niektórych ustaw w zakresie działań osłonowych w związku z rozprzestrzenianiem się wirusa SARS-CoV-2, Dz.U. z 2020 r., poz. 875 . 
Rozporządzenie Ministra Zdrowia z dnia 7 grudnia 2001 r. w sprawie postępowania ze zwłokami i szczątkami ludzkimi, Dz.U. z 2001 r. Nr 153, poz. 1783.

Rozporządzenie Ministra Zdrowia z dnia 21 października 2016 r. w sprawie wymagań i sposobów unieszkodliwiania odpadów medycznych i weterynaryjnych, Dz.U. z 2016 r., poz. 1819.

Rozporządzenie Ministra Zdrowia z dnia 5 października 2017 r. w sprawie szczegółowego sposobu postępowania z odpadami medycznymi, Dz.U. z 2017 r., poz. 1975.

Rozporządzenie Ministra Zdrowia z dnia 13 marca 2020 r. w sprawie ogłoszenia na obszarze Rzeczypospolitej Polskiej stanu zagrożenia epidemicznego (Dz.U. poz. 433).

Rozporządzenie Ministra Zdrowia z dnia 20 marca 2020 r. w sprawie ogłoszenia na obszarze Rzeczypospolitej Polskiej stanu epidemii (Dz.U. poz. 491 ze zm.).

Zarządzenie Wojewody Małopolskiego, nr poz. rej. 142/20 z 3.04.2020 r. w sprawie zmiany częstotliwości odbierania wybranych frakcji odpadów komunalnych na terenie Miasta i Gminy Myślenice, Dz. Urz. Małop. poz. 2701.

\section{Orzeczenia}

Uchwała TK z 2.03.1994 r., W 3/93, Dz.U. Nr 36, poz. 137.

Wyrok TK z 10.11.1998 r., K 39/97, LEX nr 34601.

Wyrok Sądu Apelacyjnego w Gdańsku z dnia 27 września 2017 r., sygn. I ACa 1201/16, LEX nr 2446575.

\section{Inne źródła}

https://www.rpo.gov.pl/pl/content/koronawirus-starosta-wysokomazowiecki-niemial-na-mysli-stygmatyzowania-chorych (dostęp: 19.05.2020).

Waste management in the context of the coronavirus crisis, https:/ec.europa.eu/info/files/ waste-management-context-coronavirus-crisis_en (dostęp: 19.05.2020).

Wytyczne Ministra Klimatu i Głównego Inspektora Sanitarnego w sprawie postępowania z odpadami wytwarzanymi w czasie występowania zakażeń koronawirusem SARS-CoV-2 i zachorowań na wywoływaną przez niego chorobę COVID-19 (w czasie trwania pandemii/epidemii), file://C:/Users/user/Downloads/Wytyczne_ dot_post\%C4\%99powania_z_odpadami_w_czasie_wyst\%C4\%99powania_zaka\%C5\%BCe\%C5\%84_koronawirusem_SARS-CoV-2-2.pdf (dostęp: 12.05.2020).

Ministerstwo Środowiska, Wytyczne do sporządzania wniosku o wydanie pozwolenia zintegrowanego, https://ekoportal.gov.pl/fileadmin/Ekoportal/Pozwolenia_zintegrowane/poradniki_branzowe/opracowania/Wytyczne_do_sporzadzania_wniosku_o_wydanie_PZ.pdf, online 18.10.2020 r., s. 12 . 